\title{
緑地帯の大気浄化機能に関する研究 一特に自動車走行に伴ら粉塵の葉面吸着量について一

\author{
三 澤彰* \\ Studies on Atmospheric Purification as a Function of \\ Buffer Planing Belts on Roadsides
} \\ -Experiments on Trapping Particulates by Foliage-
}

Akira MISAWA

\begin{abstract}
摘要 : 自動車走行に伴なう大父污染のなかでも粒子状物質による污染は最近問題になり始めたものである。本論文で は沿道緩衝緑地带の機能の1つとして群葉による粒子状物質の吸着量を定量化することを目的に野外実験を実施し た。その結果, 葉面による粉塵吸着量は, 群葉近傍の粉應濃度及び暴露期間にほぼ直線的に相関すること, 樹葉形態 に著しく関係することなどを明らかにできた。これを基に沿道緩衝緑地带の粉塵吸着量の定式化を試みた。
\end{abstract}

\section{1. はじめに}

大気污染防止法施行令第 4 条による自動車排出ガス物 質飞は一酸化炭素 $(\mathrm{CO})$, 炭化水素 $(\mathrm{HC})$, 鉛化合物, チッン酸化物 (NOx) 粒子状物質が上げられているが, $\mathrm{NOx}$ や $\mathrm{HC}$ が太陽光の柴外線による光化学反応汇よっ て生成される光化学スモッグ（オキシダント）も二次的 な污染質ではあるが，大きな問題となっているものであ る。また燃料の変化によって最近減少してはいるもの の, 硫黄酸化物 (SOx) も排出されている。

これらの污染質については大気污染防止法第19条第 1 項により車種別飞単位走行当りの排出許容限度量（排出 規制）が規定されている。大気污染が社会的に大きな問 題となり，しかも自動車の寄与度が高いことから ${ }^{1) ， こ ~}$ の排出規制の強化が図られて扔り，ガス状污染質泀つい てはいずれる昭和 48 年規制の $1 / 10$ 以下に招さ兄られよう として扮り（昭和 $51 \cdot 52$ 年規制）いわゆる発生源対策の 効果が現われ始めている22。な扔，鉛化合物とついては 東京, 柳町交差点飞括ける鉛公害（昭和44）を始め各地 での問題発生を契機に現在は燃料中の鉛含有量が大幅に 規制されている。一方，粒子状物質（微粒子）について は，現在ディーゼル黒煙についてのみ規定されている が, 最近, この排出ガス中の微粒子 (Perticulate) が呼 吸器系の病気や発ガン性を有すること，さらにその排出 量が多いディーゼル車の普及が燃費などの影響から飛躍 的飞増加していることから, 米国環境保護局 (E.P.A) では1982年型車からそその規制をしょうとしている（朝

\footnotetext{
* 千葉大学園芸学部㻴境緑地学科
}

日新聞・昭和55年 2 月 22 日夕刊)。これによれば 1982年 型車から乗用車, 小型トラックとも亿走行距離 $1.6 \mathrm{~km}$ 当 り $0.6 \mathrm{~g}$ 以下, 1985 年型車が乗用車 $0.2 \mathrm{~g}$ 以下, 小型卜ラ ック0. $26 \mathrm{~g}$ 以下となっている。この微粒子は, 粒径が 5 $\mu \mathrm{m}$ 以下（特飞 $1 \mu \mathrm{m}$ 以下）のむのが多く, 環境基準に 定められている浮遊粒子状物質の粒径 $10 \% \mathrm{~m}$ 以下之比較 してかなり微小なものである。

これらの自動車走行と伴なう環境压 (Environmental Impact）飞対して,「環境施設帯制度」、「沿道環境整備 制度」など一連の法制度が施行され現在実施されつつあ るが，緑地带はそれらの対策の中でも主要な施設として 位置付けられている。しかし, その効果についてはいま だ末解決の点が多く、その計画・設計にあたって現実に はかなりの混乱がある。本研究は以上の背景を踏まえ, 自動車走行に伴なう沿道空間への環境圧のうち, 特飞微 粒子飞焦点を絞り, 緑地带の有与る吸着効果の定量化を 試みたものである。

\section{2. 樹林の大気浄化効果の機作}

図一 1 は, 樹林の大気浄化機能の一般的な機構を概念 的に示したむのである。

拡散とは，污染された空気の流れが樹冠飞沿って上空 へ流動することによって生ずるもので, 効果としては希 釈と同様であり，污染質の絶対量（総量）は減少しな い。従って拡散は防風効果飞準じて考兄られ, 上り上層 の気流飞乗らない限り（樹林程度の高さでは期待できな い)。污染質は樹高の 10 倍〜20倍 ${ }^{3}$ 離れた風下側の地点 飞降下する。この時, 污染された空気は上空の污染され ていない空気によって希釈される。すなわち，この効果 


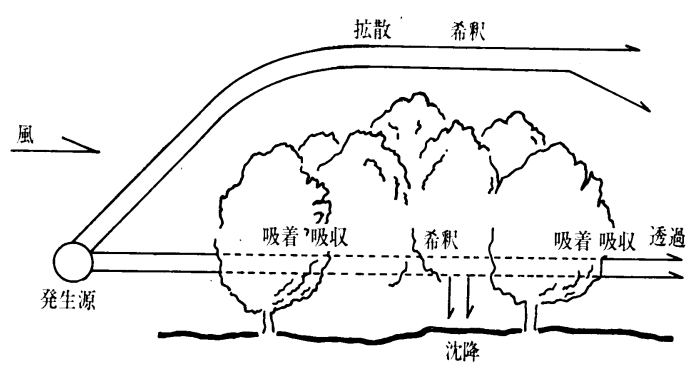

図一1 樹林の大気浄化効果

は污染物質の発生源をその樹林の高さまで上昇させるこ とによってもたらされるもので, 各種の拡散理論て扔い ても, 污染物質の濃度を減少させる効果は期待できるも のの, 絶体量の減少にはならないということである。

希釈は，拡散炕よってももたらされるが，樹林内を透 過する過程に扔いて樹林内の相対的飞清净な空気によっ ても,もたらされる。後者の希釈は樹林の容積が大きい 程大であると考兄られる。

沈降は, 樹林内の気流の流速が, 樹林外のそれより弱 まり停滞することによって生じ，特飞空気より比重の大 きな污染質の場合は顕著である。

吸収とは, 植物の生理作用, なかでも同化作用, 呼吸 作用飞共なって, 污染質が植物体組織内ととり込まれる ことをいい，他の方法では除去しにくいガス状污染質に 対しても効果が期待できる。この効果は植物の生理作用 の速度によって影響されるものと考兄られ, 植物の種類 飞よる差はもちろん, 季節的な変動も大きく, 主飞気孔 開度との関連に扔いて捕えることができよう。

吸着とは, 污染質が植物の外表面飞付着することで, 特飞植物の枝葉形態, 寸なわち, 展葉形態, 葉表面の構 造（鋸歯, 軟毛等の有無など）に大きくかかわってい る。

以上の樹林の大気浄化機能の弓ち, 抎散, 希勫以外の 沈降, 吸収, 吸着効果によって捕捉された污染質は, 最 終的には樹林内の土壤飞固定される。また，拡散を除く 4 種類の効果は, いずれも植物の量（緑量）飞相関する ものと考兄られる。

\section{3. 固体污染質と気体污染質}

植物の有する大気浄化機能について考兄る場合, 污染 質が固体（浮遊粉魔. mist を含む）であるか, 気体（ガ ス状污染質)であるかによって分ける必要がある。樹林 の大気浄化効果（図一1）のうち, 最も重要である吸着 効果之吸収効果もとれぞれ, 吸着効果一固体（浮遊粉塵 mist) ・吸収効果一気体（ガス状污染質）とわけること ができる。浮遊粉塵であっても，その粉径が自動車排出 粉痤の場合, $5 \mu \mathrm{m}$ 以下のいわゆる微粒子 ${ }^{4}$ （特飞 $1.0 \mu \mathrm{m}$
以下のものが多い）であり，この大きさは，植物の種類 そよってかなり変化するが一般的な植物の気孔の大きさ が長径 $20 \mu \mathrm{m}$ 前後, 短径 $3 \mu \mathrm{m} \sim 5 \mu \mathrm{m}^{5)}$ であることから, 十分に植物体の組織内に吸収され得る。しかし, 開度状 態飞おける場合でもその気孔面積 (中央隙) は一葉中数 \%程度のもので表裏を考光れば，さらにその $1 / 2$,すな わち, 全表裏面積の $1 \%$ 前後程度のものとなり, しか も, 気孔開度の時期はかなり制限されるし, 葉以外の植 物の器官一幹 (trunk)・枝 (blanch)・ 細枝 $($ stem) ・ 花 ・果実などーの表面積は, 葉のそれに比へて圧倒的に小 さい。つまり, 浮遊粉魔は主に葉による吸着効果によっ て浄化される。ガス状污染質についても, 葉の吸収効果 以外によって浄化されることは微少である。ただし, 浮 遊粉塵飞吸着したガス状污染質が、その浮遊粉塵と共に 吸着する効果は考虑する必要がある。

\section{4. 東名高速道路日本坂トンネル東口付近における葉 面の粉塺吸着量測定実験}

(1) 目的

日本坂トンネル東口付近は, 開通当初（1969年）から 同トンネル坑口からの自動車排出ガスが, 付近一帯のミ カン樹に被害を及ぼしている所で，1977年に集蝔機を卜 ンネル坑口に設置したが, 現在でも浮遊粉蝔をはじめ, かなり高濃度のガス状污染質が排出されている所であ る。このようと污染質の発生源が自動車のみで, かつ. 高濃度飞污染された場所を利用して, 污染濃度別, 経時 別, 樹種別飞, 樹林の吸着能力の特性を検討することが ここでの目的である。

(2) 方法

調查は, 1979年 9 月27日（試験植栽木を植込む）から 1980年 1 月 12 日までの 3.5 ケ月の間, 定期的に 5 回実施 する。

対象樹種としては, トンネル事故（1979年 7 月・下り 線内）後, 当局によって防煙林として植栽されたカイズ カイブキ (Juniperus chinensis Linn. Var. Kaizuka Hort.)・シャリンバイ (Raphiolepis umbellata Makino) 及び，当初より植栽されていたネズミモチ (Ligustrum japonicum Thunb.) ・ドラ(Pittosporum tobira Ait.) ・ヒノキ (Chamaecyparis obtusa sieb. et Zucc.) ・ス キ (Cryptomeria japonica D. Don.) などであり, それ 飞今回試験植栽した，低木一ハナン゙ノックバネウッギ (Abelia grandiflora Rehd.)・サッキッッジ (Rhododendron indicum Sweet.)・オオムラサキ (Rhododendron omurasaki Makino.)・中木ーサンゴジュ (Viburnum awabuki K. Koch.)・ネズミモチ・マサキ(Euonymus japonicus Thunb.)・サザンカ (Camellia sasanqua Thunb.)・高木 (苗木)一ケヤキ (Zelkova serrata Makino.)・トウカエデ (Acer buergerianum Miq.)・ 


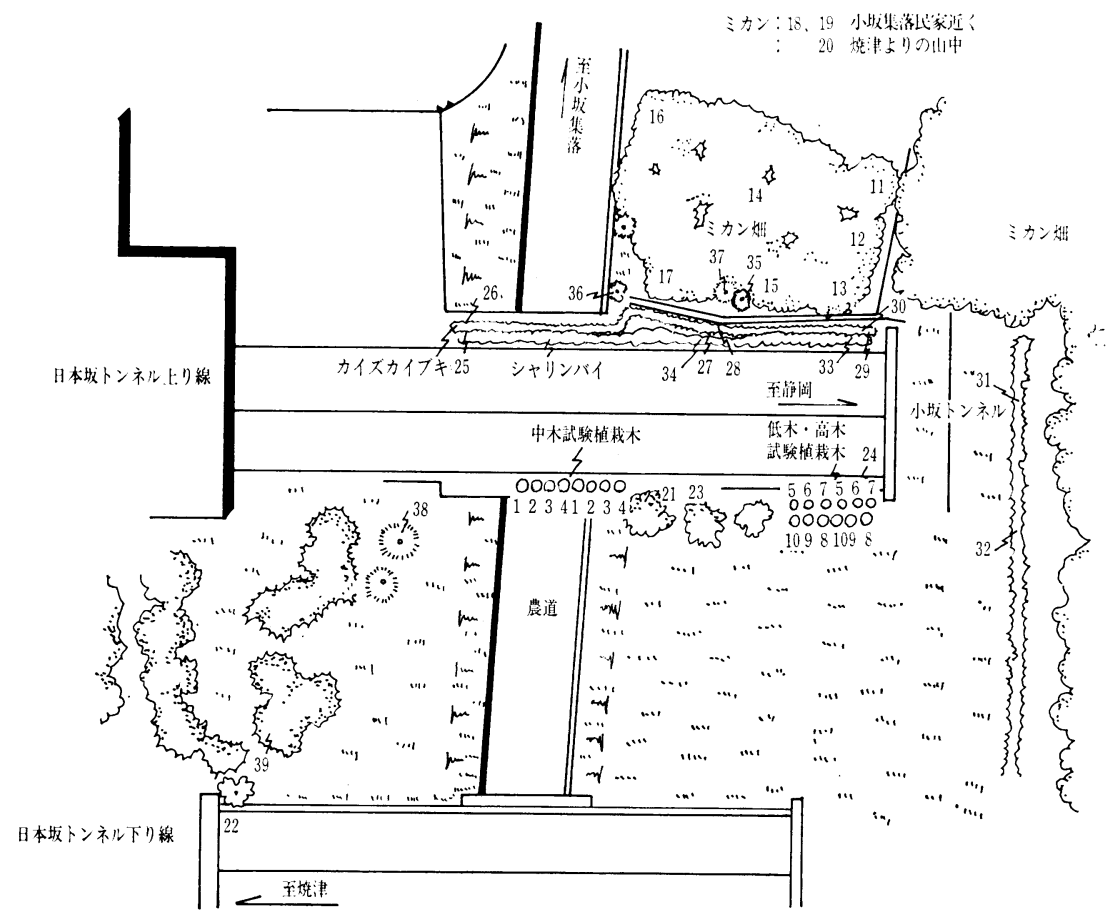

図一2 東名高速道路日本坂トンネル東口付近調查対象木及び大気粉塺濃度測定位置図

イチョウ (Ginkgo biloba Linn.) を加える。供試した 樹木の選定にあたっては, 現在一般に緑化樹木として多 用されていること, 葉の形態（鋸㐘・葉毛の有無など） に差のあることなどを考慮している。植栽簓所は眓一 2 のと打りで, 浮遊粉塵濃度の比較的高いと思われる地点 を選定している。

i ) 污染濃度別測定 道路沿いに植栽されているカ イズカイブキと傾斜地一带に植えられているミカン樹に ついて, 本線に面した側の地上約 $1.5 \mathrm{~m}$ 高の葉を, 合計 して扮よそ $100 \mathrm{~cm}^{2} \sim 200 \mathrm{~cm}^{2}$ になるように，あらかじめ

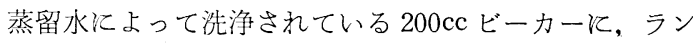
ダムに採取する。同時に，第 4 回目の測定日，1979年12 月14日（测定時の天候は無風, 晴れ）には, 各葉のサン プリング地点の地上高 $1.5 \mathrm{~m}$ において, 浮遊粉塵量を RION-TECE WORLD model FC-250 "Particle Counter”により $36 \mathrm{sec}$ 連続計測— $30 \mathrm{sec}$ 間隔で粒径別 (0.5 $\mu \cdot 1.0 \mu \cdot 2.0 \mu \cdot 5.0 \mu \cdot 10.0 \mu の 5$ 段階) 飞10回测定し, その平均值を求め, これを同一地点でほぼ同一時期に测 定された重量濃度を参考に, 重量濃度で示した。

ii）経時別測定 全対象木について地上約 $1.5 \mathrm{~m}$ 高の 本線に面した側とその裹側の葉を1979年 $9 / 27 \cdot 10 / 4 \cdot 10$ $/ 31 \cdot 12 / 14 \cdot 1980$ 年 $1 / 12$ と経時的に 5 回サンプリングし ている。その間の気象条件を静岡地方気像台のデータに よって調查し, 経時的な粉塵吸着量の増減を検討する。

iii）樹種別測定 ii )でサンプリングした葉を利用
し, 主に葉の形態別に吸着量を求め, 実体顕微鏡 (オリ ンパス実体顕微鏡 X-Tr 型，倍率20８0倍）で吸着状態 を観察し、スライド写真を撮る。

iv）吸着粉塵量等の計量・分析方法

サンプリング葉を葉が浸るまでビーカーに蒸留水を入 れた後, 超音波洗浄器 (BRANSON IC 220) で30分〜 40分間洗浄する。このビーカー内の液をあらかじめ乾燥 計量した沪紙（東洋汇紙製 MEMBLAN FILTER TM$50.1 \mu \mathrm{m} 47 \mathrm{~m} / \mathrm{m}$ ) を使用し, 沪過器 (MILLIPORE 製 $47 \mathrm{~m} / \mathrm{m}$ 用 $\mathrm{ORE}$ ) で沪過する。この時使用する吸引ポン プはヤマト科学株式会社製真空ポンプ MINI-VAC PS05型である。沪過後, 沪紙を乾燥させ, 直示天称 (Tokyo kok SEIZOSHO 製) で0.1mgな゙計測し，あらかじめ計 測しておいた沪紙の重量を引き，吸着粉塵量の重量を求 める。

供試葉は, 洗浄後, 自動面積計（林電工株式会社 製 A AM-7）を用いてその葉面積を 3 度計測し, 平均を求 めた後, 絶乾状態にして葉の乾燥重量を計测する。以上 の過程の後, 単位面積あたりの吸着粉塵量 $\mathrm{mg} / \mathrm{dm}^{2}$. 及び 単位葉乾量あたりの吸着粉魔量 $\mathrm{mg} / \mathrm{g}$ を求めている。

な括, 吸着粉魔の成分分析は, ヘンゼン可溶性有機物 及び灼熱損失量について行なっている。

(3) 結果

i ) 污染濃度別吸着量 図一 3 は, カイズカイブキ 污染葉と, そのサンプリング箇所に括ける浮遊粉塵濃度 


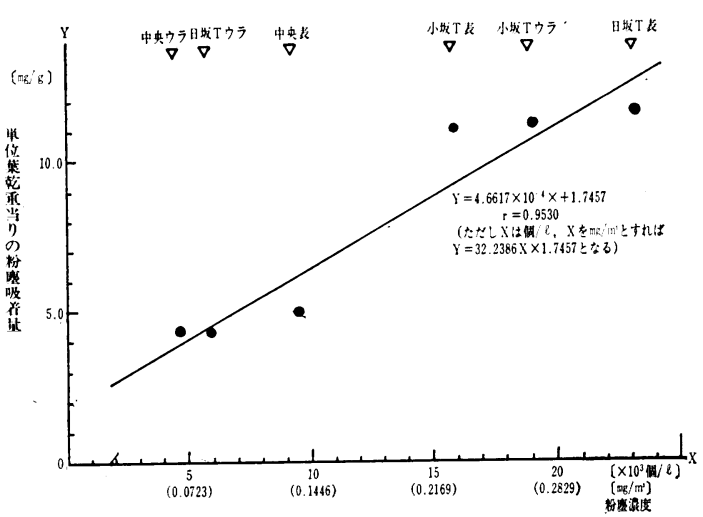

図一3 カイズカイブキ浮遊粒㢕濃度と粉塵吸着量 の回帰式

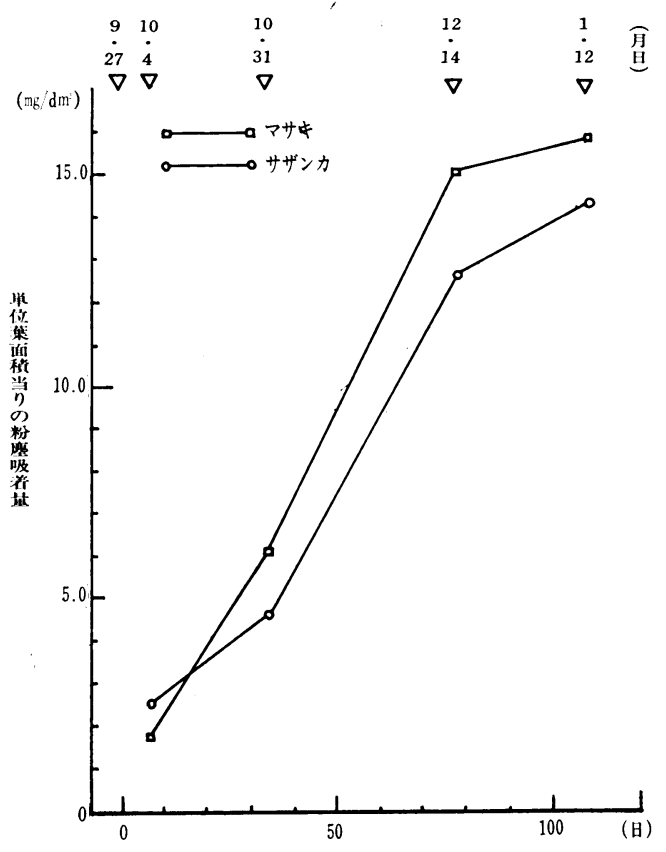

図-4 供試木の粉歴吸着量の変化 (1)

との関連を調べたものである。粉塵濃度が $10 \times 10^{3} /$ コ 以下と, $15 \times 10^{3}$ コ/ $\ell$ 以上の 2 グループに別れてしまっ ているが，粉塵濃度が増すに従って一般に葉面の粉塺吸 着量も增大している。これを直線的に回帰できるものと して求めた式が図中の回帰式である（図中カッコ内の数 值は，ほぼ同時期に测定されたトンネル坑ロでの重量濃 度表示による测定值を基に換算したもの)。

ii）経時別吸着量 図一 $4 \sim$ 図-6は, 1979 年 9 月 27日に試験植栽した樹種について, 粉塵の葉面吸着量の 変化を追求したものである。調査は, 天候その他の理由 により，必ずしも一定期間ごとには行なわれていない が, 一様に増大していく傾向を示している。眓一 4 ・図 一 5 そ扮いて, その増加傾向を見ると, マサキ・サザン

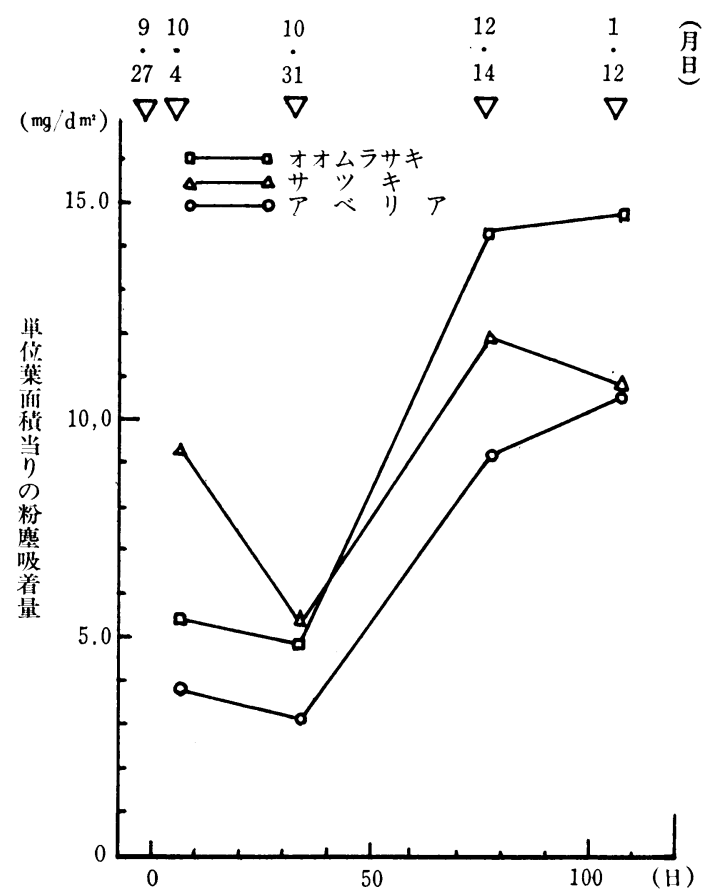

図一5 供試木の粉塺吸着量の変化（2）

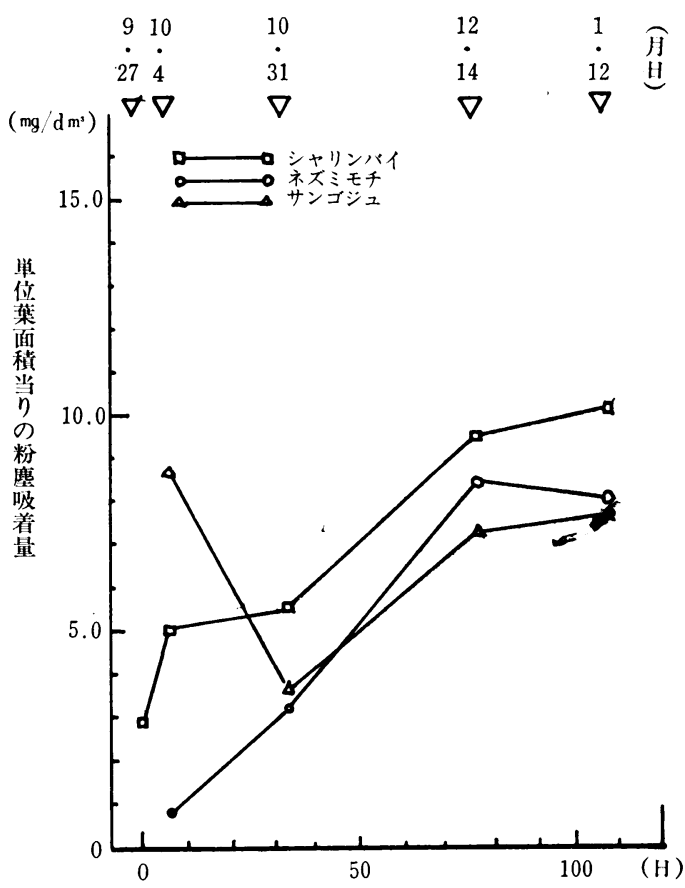

図-6 供試木の粉塺吸着量の変化 (3)

カの 2 種が, 他のトベラ・シャリンパイ・ネズミモチ・ サンゴジュの 4 種と比較して大きい。これは前 2 種の一 枚あたりの葉面積が比較的小さいこと，及び，鋸歯があ ることなどにより，形態的には判断できるものである。 この 2 つのグループごとにその回州式を求めたものが図 


\section{-7の式である。}

ただし，10月 4 日のデー夕は試験植栽以前の苗固にお ける畑土の付着によるものと考兄られる異状があり, 四 一 5 に拈けるサンゴジュのこの日のデータは計算から除 外してある。図一 6 の10月31日のデータで, 一様に低い 值となったのは, その後, 畑土等の灰分質が降雨, 風等 そよって落下, 流亡したためと判断される。図一 9 は, その間の気象データである。

図一8は, カイズカイブキについて, 平均濃度別の吸 着量を経時的に求めたものである。

iii）樹種別吸着量 樹種別吸着量の差は, 前出した 図一 7 にって示される。植栽箇所の大気粉塵濃度が異 なるため，一概に比較することはできないが， ii）でも 述べたと扮り，中木ではマサキ・サザンカが他のネズミ モチ・サンゴジュ・シャリンパイよりも吸着量が多い。 低木ではオオムラサキの吸着量が多く, サッキツツジ・ ハナゾノックバネウッギの順に少なくなっている。これ

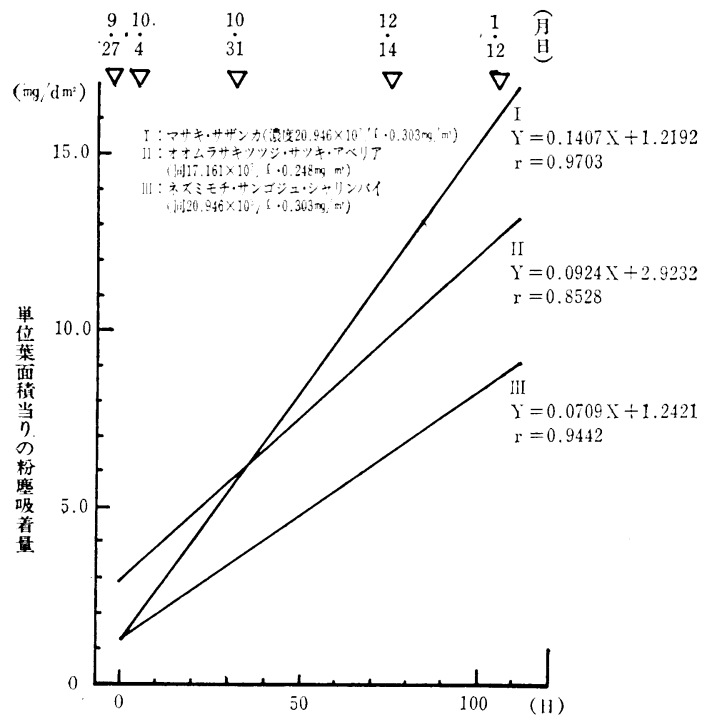

図一 7 供試樹木の粉塺吸着量の回帰式
は葉面の毛の長さ及び量に関連しているものと考觉られ る。

これらの葉面の粉塵吸着状態を顕微鏡によって観察し た結果は次のと括りである。

ア, 葉身に毛の無いもの（広葉樹）

○始めに葉縁, 葉の先端部の凸部に細かい粉應（10 $\times 10 \mu \mathrm{m}$ 以下) がつく。

○葉に凹凸があれば，凸部に細かい粉塵がつきやす w。

○表裹共に, 先端部, 葉縁の吸着量が多く, 葉柄よ り少し上部の葉縁と葉脈の間の吸着量は少ない。 吸着量が多くなると, 葉縁, 先端部, 葉脈の凸部 がはげてくる。

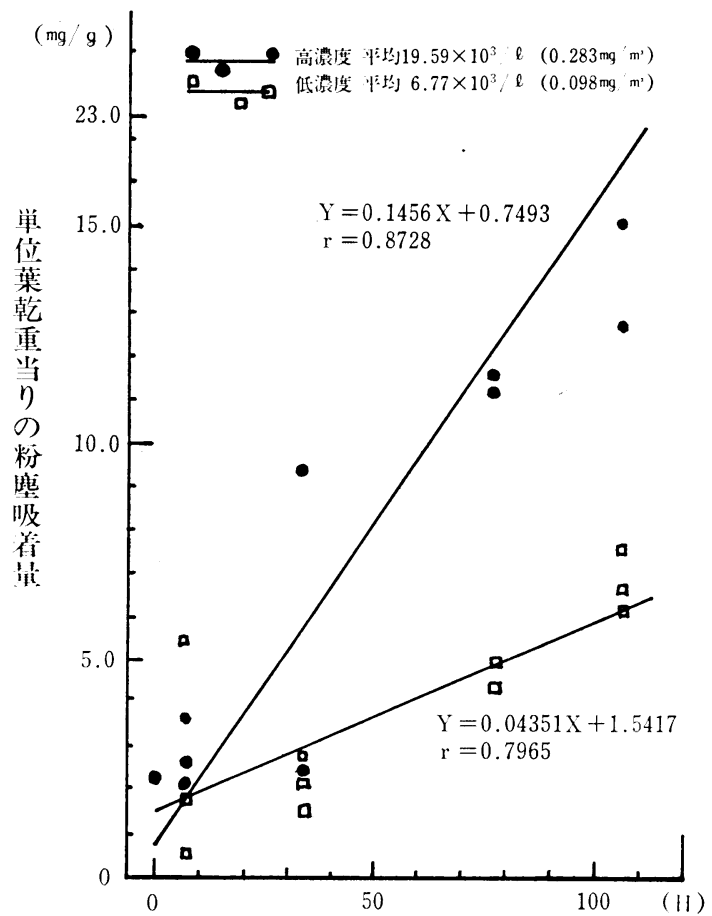

図一8 カイズカイブキ・粉塵吸着量の回帰式

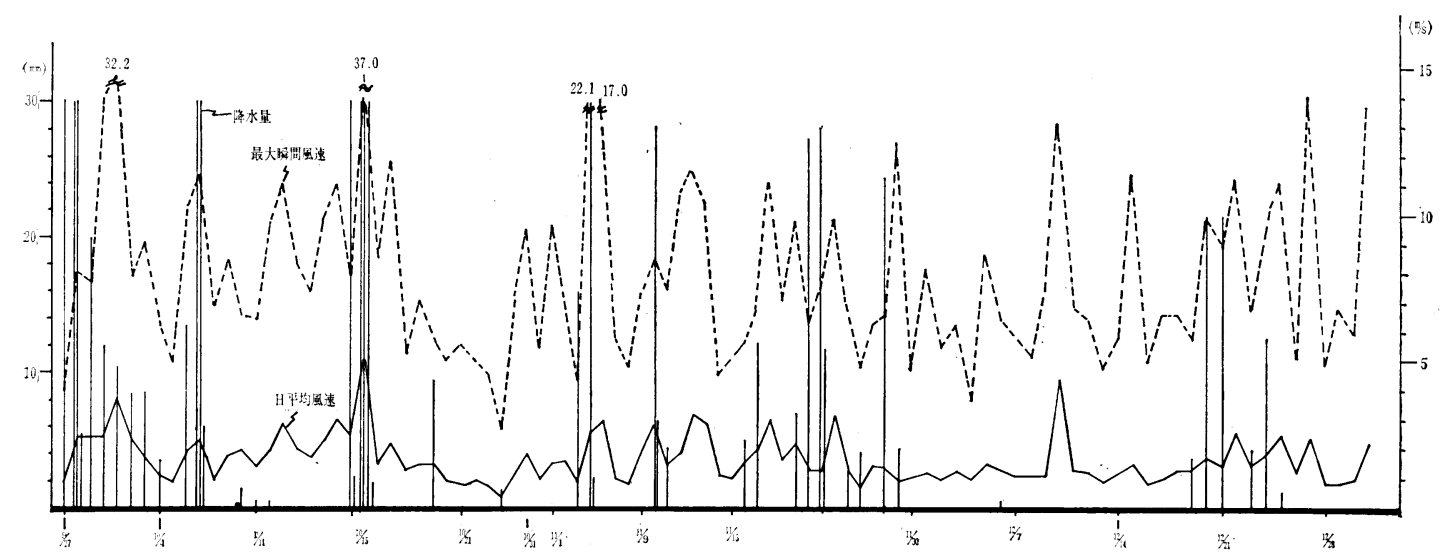

図一9 調査期間中の気象条件（静岡地方気象台データより） 
○葉脈の凸部々細かい粉塵が付着し, 脈の筋にその 粉塵が入るうになり, やがて $30 \times 30 \mu \mathrm{m}$ 程度に 肥大した粉塵が脈全体についてくる。脈の両側の 凹部には，比較的径の大きい粉塵が集まる。

○細かい粉塵の層の上に $30 \times 30 \mu \mathrm{m}$ 程度に肥大した 粉塺や砂加吸着する。

○特に裏の葉縁近くに粒径の大きい粉塵が多くつ <。

○ある程度粉塵が付着した場合, 表には細かいも の, 裏には粒径の大きい粉塵が多く, 全般的にみ ると表の吸着量が多い。

○葉縁に鋸䨑のあるものは凹部に多く吸着する。

イ, 葉身全体に毛があるもの（広葉樹）

○先端部, 葉縁の毛先がまず黑くなり, 付着量が多

くなるにつれて表面が污れてくる。

$\circ 30 \times 30 \mu \mathrm{m}$ 程度の大きい粉塵は, 表より裹に多

く, 毛先, 毛の間に吸着する。

。毛が密生している所，たとえば葉柄近くなどでの 吸着量が大きい。

ウ, 新葉（ケヤキ・トウカエデ・イチョウ・シヤリン (イイ)

○毛のあるものは, 葉縁, 葉脈上の毛の先が黒くな り始め, 粒径の大きな粉應は, 毛の密生している 所や，葉脈の内側などに多く集まる。

○イチョウでは, 粉塵が始めその先端部, 凸部に付 着する。粒径の大きなものは, 葉縁, 葉柄近くの 凹部に多い。

工, 針葉樹

○細かい粉塺はまず鱗片葉の凸部，スギでは陵など に吸着してゆく。

\section{5. 都内幹線道路沿い緑地における葉面粉塺吸着量の 測定調査}

(1) 目的

交通量の多い（道路公害の発生している）都内幹線道 路の緑地带や, 都市公園の樹木について, その粉塵吸着 効果及び飛散防止効果などの実態を調査することを目的 とする。

(2) 万法

測定場所は, 練馬区豊玉北の環状 7 号線沿いの街路緑 地帯（図一10）及び，世田谷区の環状 8 号線に面する芦 花公園内の緑地（図一11）で, 測定日は共に, 1979年10 月27日である。

調査対象樹木は，環状 7 号線では，クスノキ(Cinnamomum camphora Sieb・H $=5.5 \mathrm{~m})$, サンゴジュ (Viburnum awabuki $\mathrm{k}$. Koch $\cdot \mathrm{H}=1.8 \mathrm{~m}$ ), オオムラサキ (Rhododendron omurasaki Makino $\cdot \mathrm{H}=0.5 \mathrm{~m}$ ) の計 3 種, 芦花公園では, クスノキ (Cinnamomum cam-
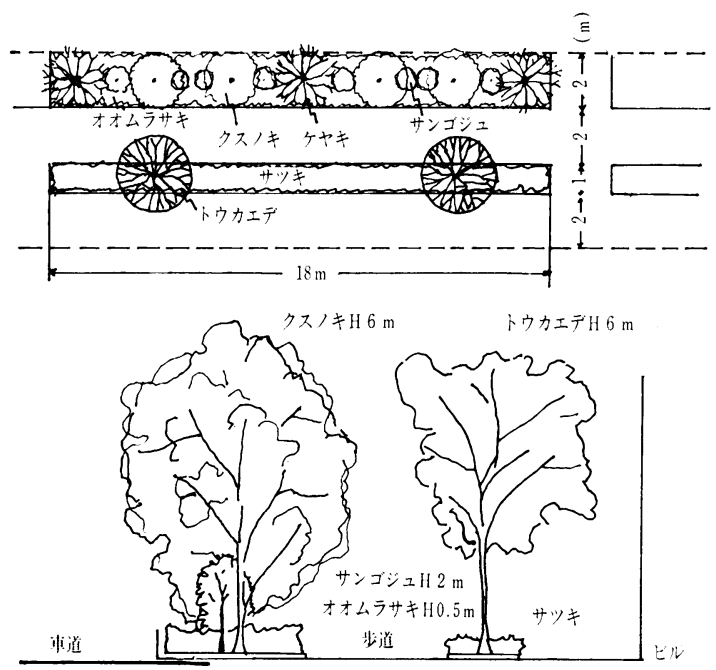

図一10 東京都練馬区豊玉環 7 通り街路樹略図

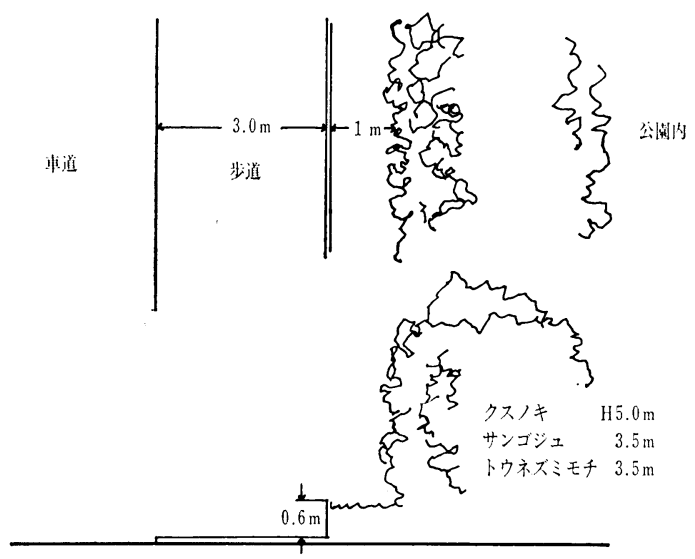

図-11 東京都世田谷区環 8 芦花公園の緑地略図

phora $\mathrm{Sieb} \cdot \mathrm{H}=3.5 \mathrm{~m}$ ), ネズミモチ (Ligustrum japonicum Thunb・H=3.5m), サンゴジュ (Viburnum awabuki k. Koch・H=3.5) である。

葉のサンプリング箇所は, 環状 7 号線のクスノキは, 樹木の車道側と歩道側でそれぞれ 地上 $0.5 \mathrm{~m} \cdot 1 \mathrm{~m} \cdot 1.5$ $\mathrm{m} \cdot 3 \mathrm{~m} \cdot 4.5 \mathrm{~m}$ の高さ別に計 10 ポイントであり, サンゴ ジュ・オオムラサキについては, 車道側, 歩道側別にそ れぞれ地上 $0.5 \mathrm{~m} ・ 1 \mathrm{~m}$ の高さ別に計 4 ポイントずつであ る。環状 8 号線の樹木についても同様に, 地上 $1.5 \mathrm{~m} \cdot 3$ $\mathrm{m}$ の高さ別に車道側と公園側で葉のサンプリングを行な う。サンプリングオ法, 分析方法は 4, (2)iv) の日本坂卜 ンネルでの测定に準じている。

同一地点に沶いて,地上高別飞前述のParticle Counter によって, 大気中の浮遊粉塺濃度を求める。

(3) 結果

测定結果は, 図一12・図一13のと打りである。環状 7 号線の場合は, 東名高速道路日本坂トンネル付近の測定 より，全般に大きい值を示しているが，それは，植栽後 


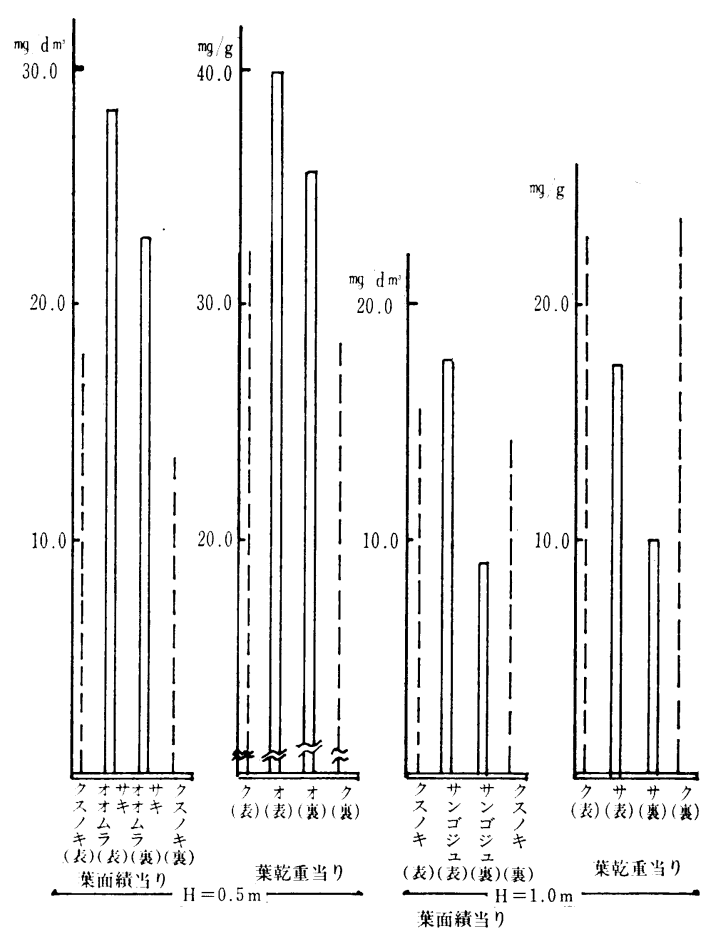

図-12 車道側一歩道側別粉塺吸着量 （於豊玉 1979. 10/27）
かなりの年月を経ているもので，展葉期からサンプリン グまでの間が長いこと, 及び, 浮遊粉濃度が高いことに もよろうが，特飞地上高 $0.5 \mathrm{~m}$ での值が大きいのは, 路 面からの砂塵などが含まれているためである。樹林の車 道側, 歩道側の部位別では, サンゴジュの地上高 $1.0 \mathrm{~m}$ そ招いて，歩道側は車道側の約 $1 / 2$ 飞減少している。ク スノキ及び地上高 $0.5 \mathrm{~m}$ そ扔けるオオムラサキでは, そ れ程顕著な差はないが，クスノキについてみると，高さ $4 \mathrm{~m}$ 程度までは低い程との差があり，4 mを超えると差 がなくなる傾向を示している。図一14は，クスノキの吸 着量を部位別に示している。これとよると，かなりはっ きりと車道側・歩道側共飞高くなると徉って吸着量は減 少している。

環状 8 号線とついてみると, 車道側の吸着量の方が多 かったが，歩道側との差は $1 / 10 \sim 1 / 3$ 程度である。これ はサンプリング位置（緑地）が，車道からかなり離れて いる（平均 $4 \mathrm{~m}$ ) ことが影響していると考兄られる。全 般飞, 環状 7 号線のデータに比べて小さい值を示してい るのは, 車道からサンプリング地点までの距離の差, 及 び，交通量の差によるすのと思われる。

表一 1 は, その他の主要幹線道路沿いの緑地において
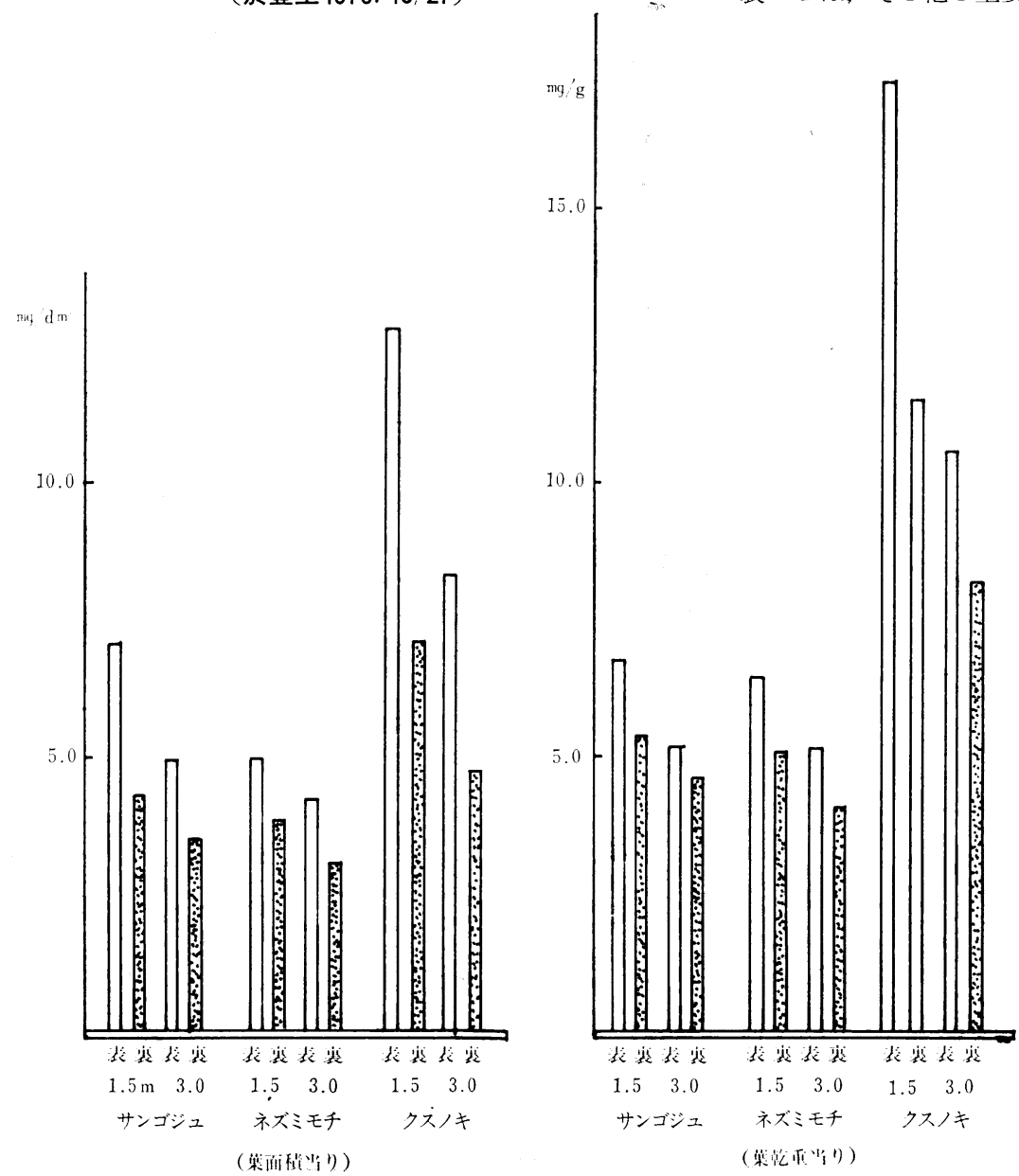

図-13 車道側一公園側 別の粉塵吸着量 （於芦花公園 1979 10/27) 
同様の方法により測定した各樹種の葉面粉塵吸着量を示 したものである。

\section{6. 考 察}

(1) 樹種別特性

葉身自体の形態，あるいは着葉 (展葉) 形態は樹種に よって多くの変化がある。たと光ば，葉縁 1つとってみ ても, 全縁, 波形, 鈍鋸歯, 鋸歯, 重鋸歯, 歯牙, 毛縁 などと,多くの種類に分類されている。このような分類 が, 葉毛や葉の切れこみ, 葉脈, 単葉, 複葉の変化, 展 葉, 葉柄の有無, 長短などにもあり, これらの葉の形態

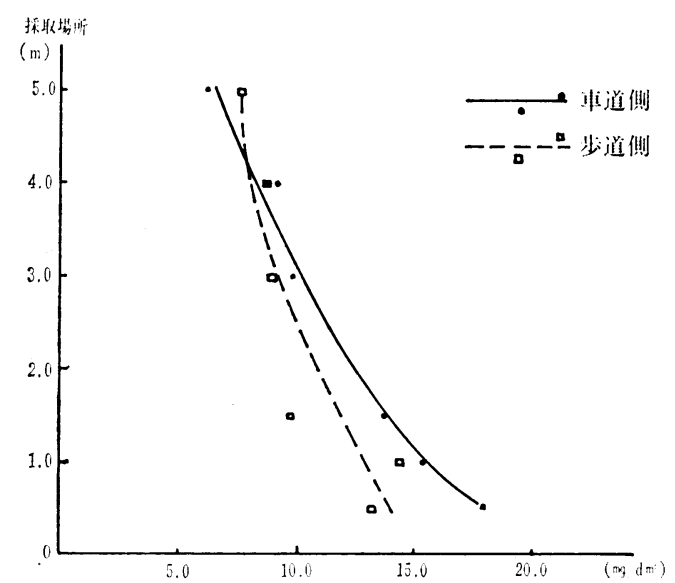

図一14 クスノキの高さ別粉塺吸着量(単位葉面積当り)
がミクロの世界である浮遊粉塵とのかかわりに招いて重 要であることは，十分考慮する必要がある。本多(6)の東 名高速道路日本坂トンネル東口に抢ける測定例飞打いて も,カイズカイブキが他の広葉樹よりも顕著な吸収量を 示している。また，同一地点での今回の測定に扔いて も, 広葉樹との比較は一概にはできないが, カイズカイ ブキは最大 $24.14 \mathrm{mg} / \mathrm{g}$ （1979年 2 月測定時の最大 36.38 $\mathrm{mg} / \mathrm{g}$ ) を記録しているのに対して、供試した 常緑広葉

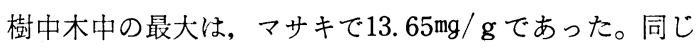
中木では, サザンカが同程度の吸着量の增加率を示し, 他のネズミモチ, サンゴジュ, シャリンバイと比較して 顕著な差がみられる。これは, 前者が比較的小葉である こと, 葉縁に鋸歯が存在することなど, 形態的に判別で きるもので，この点に関してい竞ば、カイズカイブキは 葉身長はあるが，その幅は $0.8 \mathrm{~mm} \sim 1.5 \mathrm{~mm}$ 以下である。辰 巳 7 の研究に括いても, アカシヤの吸着量が他飞比較し て大きいと述べていることにも符合するものである。今 回の測定実験の試験植栽木の中で低木についてみると, いずれも粉塵吸着量の增加率は高い。供試したオオムラ サキ, サッキッッジ、ハナゾノックバネウッキは皆比較 的小葉であり, 実体顕微鏡に上る観察の結果, 葉の表々 裹に毛が存在する。都内調查の環状 7 号線の場合でも吸 着量を比較すると,オオムラサキ $\left(28.36 \mathrm{mg} / \mathrm{dm}^{2}\right)>$ サン ゴジュ $\left(7.14 \mathrm{mg} / \mathrm{dm}^{2}\right)>$ トゥネズミモチ $\left(4.91 \mathrm{mg} / \mathrm{dm}^{2}\right)$ の順である。この順位は葉の大きさと逆相関していると

表一1 各地の幹線道路における粉塺の葉面吸着量

\begin{tabular}{|c|c|c|c|c|c|}
\hline 番号 & 樹 & 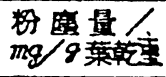 & 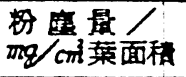 & 探取场所 & 採取時期 \\
\hline 1 & カイツカイブキ & 36.38 & & 東名日本坂トンネル & 792 \\
\hline & $\pi$ & $(0.82)$ & & (非污染地) & " \\
\hline 2 & $E>3 y$ & 10.33 & 16.94 & 東名日板トンネル & "I \\
\hline 3 & オトメツバキ & 10.04 & 16.45 & $" 1$ & "1 \\
\hline 4 & ゲっケイシ் & 16.69 & 22.17 & $" 1$ & $n$ \\
\hline 5 & タイサンボク & 7.93 & 12.31 & $" 1$ & " \\
\hline 6 & マテハシシ 1 & 20.53 & 32.42 & " & " \\
\hline & " & & 26.6 & 国道 43号 芦屋 & 78.8 \\
\hline & $n$ & & $(3.1)$ & 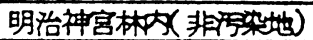 & 78.7 \\
\hline 7 & ウハメガ & 16.51 & 29.40 & 東名日本板トンネル & 79.2 \\
\hline & $n$ & & 14.6 & 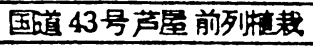 & 78.8 \\
\hline & $"$ & & 7.9 & 後列杜戈 & $"$ \\
\hline 8 & ネスミモ千 & 12.93 & 16.02 & 東名 日本坂トンネル） & 79.2 \\
\hline & $m$ & & 20.8 & 松戸民 西口交美点 & 78.7 \\
\hline & $"$ & & $(0.20)$ & 東名日本坂（非染地） & 792 \\
\hline 9 & オオムラシキツツシ் & & 26.0 & 松戸骒 西口交美点 & 78.7 \\
\hline & $\Delta$ & & 53.1 & 国道6号㻴 7 付近 & 11 \\
\hline 10 & サッキツツシ & & 124.4 & 新四木搹 & $n$ \\
\hline & $" 1$ & & 29.9 & 㳀 草 通 b & 11 \\
\hline 11 & ビラドッッシ & & 20.3 & 国道 43号芦星前列植戠 & 78.8 \\
\hline & $m$ & & 12.6 & 後列植揵 & $"$ \\
\hline 12 & 防虫ネっト（2m） & & 62.57 & 東名日本板トンネル & 792 \\
\hline
\end{tabular}


言光，粉塵吸着能からい齐ば，葉は小型である方が適し ていると考光られる。な拉, この葉の形状と葉毛の存在 とはどちらが吸着量飞大きくかかわっているかについて は，今回の実験のみでは断定できないが，以下飞ふれる と扔り衝突率飞関しては，葉の形状の方が影響するもの と考えられる。ただし，低木の場合，そのサンプリンク 位置が $0.5 \mathrm{~m}$ 以下とならざるを得ず，植栽地や路面の土 砂等の付着も当然のことながら考慮する必要がある（一 般飞, 土砂粒は浮遊粉塵より粒径も重量も大きい)。

この葉の形態と粉塵吸着能を顕微鏡により観察した結 果を考察すると，一般的傾向として粉塺は葉縁や葉脈な どのようと空気流飞触れ易い凸部に最初飞吸着する。葉 面構造が複傕な程吸着量は多く, 特飞肥大してゆく粒径 の大きなるの $(30 \mu \mathrm{m} \times 30 \mu \mathrm{m})$ が保持されるためには葉 毛根部や葉柄部などのような凹部構造が存在することが 必要である。肥大した粒径のものは葉裏て多いが，一般 的には, 粉塵吸着量は葉表に多い。結論的飞言えば, 粉 塵吸着能は, 葉自体が小型で葉面構造や展葉機構が複雑 な程良いということとなる。

斉藤 ${ }^{8}$ は, 「粒子状物質の植物群落による捕捉率(trapping efficiency) 飞扔いて, 粒子が $0.1 \mu \mathrm{m}$ 程度飞小さく なると重力落下効果を考兄る必要はなく, 粒子の移動は, 気体と同様に風によるものとみなして良い」とし，捕捉 率は衛突率によって一応の目安としている。衝突率は次 式による無次元数Kの増加関数として表わされるものと

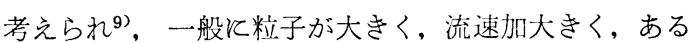
いは障害物が小さくなればなる程衝突率は大きくなると している。

$$
\begin{aligned}
K=\frac{9_{p}{ }^{2} \cdot P_{0}}{9 \nu} \cdot \frac{u}{l} & (1) \\
\text { ただし, } D_{p}, \rho_{0} & : \text { 粒子の直径 }(\mathrm{cm}) \text { 及び密度 }\left(\mathrm{g} / \mathrm{cm}^{3}\right) \\
u & : \text { 風速 }(\mathrm{cm} / \mathrm{sec}) \\
l & : \text { 障害物としての円筒の直径 }(\mathrm{cm}) \\
\rho, \nu & : \text { 空気の動粘性係数 }\left(\mathrm{cm}^{2} / \mathrm{sec}\right) \text { 及び密 } \\
& \text { 度 }\left(\mathrm{g} / \mathrm{cm}^{3}\right)
\end{aligned}
$$

4,5 での実験結果は, この理論と一致する。すなわ ち, 実験結果飞招いても障害物（葉）が小さい程, 粉塵 吸着量は多くなる傾向を示したのである。衝突率〉捕捉 率であることは当然で，そこに関与するのは葉表面の捕 捉能,すなわち，その粘着性（たとえば湿潤度 etc）な どが樹種別特性として重要となってくる。

(2) 部位別葉面吸着量の差

植栽された樹木の葉の, 高さ別や発生源飞対して表裏 別の粉塵吸着量を検討することは，次に述へる吸着量の 大気濃度との相関とほぼ同一の視点としてとらえられる べき事項であろうが、ここでは逆に，その相関を利用し て大気濃度の分布（変化）を予測できること，また，全 樹林の吸着量の総量を検討する場合の有効な手掛りそな
ることなどから 1 項を設けて考察を試みようとするすの である。

この部位別吸着量の差飞ついては, 本多6), 辰巳 ${ }^{7)}$, 門田 $\left.{ }^{10}\right)$ の報告と今回の測定結果はほぼ一致している。た だし，細部を検討すると数值付近の地形，地物（建物 等）の影響や植栽形式の相違飞よると思われる多少の開 きはあるが，一般的傾向として，高さ別々は，下方程吸 着量が多い。図一14 のクスノキの例飞示す, 地上高 0.5 $\mathrm{m}$ と $5.0 \mathrm{~m}$ の場合を比較すると, $0.5 \mathrm{~m}$ の值は $5.0 \mathrm{~m}$ の值 の, 車道側で約 3 倍, 歩道側で約 1.7 倍である。また, 発生源（車道）飞対する表裹別の差は, 植栽形式によっ てかなり差があるものの, 車道側は歩道側の拉よそ 2 倍 である。ただし，都市内道路沿い緑地ではあまり顕著な 差はみられない。その原因としては，歩道自体も粉塵の 発生源飞なり得ること, 植栽幅が極端に狭いこと, 背後 飞建物が連続して存在し污染質が停帯し易いことなどが あげられよう。

（3）大気粉塵濃度と葉面吸着量の関係

粉塵の大気中濃度と葉面吸着量との関係を測定実験し た例は過去にみあたらない。ただ，(2)で述べたようにサ ンプリング部位による測定実験の結果は，その部位にお ける大気中の粉塵濃度の差によるものと考兄ざるを得 ず,このように考えれば, 濃度と吸着量の関係は, Keller ${ }^{11)}$ 亿打いても，本多，辰巳飞扔いても测定されて 抢り，その結果は，ほぼ同様の傾向を示している。今回 の東名高速道路日本坂トンネル東口に扔けるカイズカイ ブキを対象とした測定実験は，この傾向が直線的関係で あることを明確にした（粉塵濃度と吸着量については, 1979.2 2打ける同一個所での同一方法による測定例があ るが、ほぼ近似の傾向を得ている)。すなわち，粉㾮吸 着量と大気中の浮遊粉塵濃度との関係は, 次の一次式に よって表わされる。

$0.07 \mathrm{mg} / \mathrm{m}^{3}<X<0.36 \mathrm{mg} / \mathrm{m}^{3}$, 粒径 $0.5 \mu \mathrm{m}$ 以上の場合

$$
Y=32.2386 X+1.7457(r=0.9530)
$$

ただし， $Y:$ 粉塵吸着量 $(\mathrm{mg} / \mathrm{g})$

$$
X: \text { 大気中の浮遊粉塵濃度 }\left(\mathrm{mg} / \mathrm{m}^{3}\right)
$$

前式で定数項1.7457は, 大気に抢ける浮遊粉塵濃度に 関係なく, 初めから吸着していた量及び䛊差と考觉れば 比例定数 32.2386 は, 単位当り濃度の葉面吸着量の增加 率である。

葉面吸着量は, 大気に打ける浮遊粉塺濃度（粒径 0.5 $\mu \mathrm{m}$ 以上） 飞直線的比例関係飞あるという結論が出たわ けであるが，当然のことながら，その比例関係には濃度 限界があるはずで，それは，次に述べる経時変化，すな わち，暴露期間との関連に括いて考察しなければならな い。また樹木の生育条件からも，そのクライテリアは存 在しょう。

(4) 経時的変化 
葉面吸着の経時的変化については，辰巳 ${ }^{7)}$ が同一年の 5 月と 9 月に扣ける測定の差異を示している。この中 で, 20mm程度の降雨量によって葉面に付着した污染質の 90\%以上が溶脱するとしているが，この結果は納得でき ない。特に，タール状污染質が，少ない万でも70\%強溶 脱するという結果は, 従来からの観察や測定結果にも反 するものであり，今回の測定実験に打いても，図一 9 の と㧍り，その間にかなりの降雨量があったにもかかわら ず, ほとんどの調査対象樹木について, 粉塵の葉面吸着 量は経時的に一様に增加しているのである。その増加量 は樹種によって差があり，この点に関してはすでに(1)で 述べたと括りである。しかし，辰巳が指摘していると拉 り, 灰分など, 污染質の種類によっては, 降雨や強風に よって落下, 流亡することは十分考えられる。その傾向 は, 今回の研究においても, 植栽地の土砂などの付着し やすいと思われる低木類（オオムラサキ他 2 種）にみら れ，いずれも，10/4〜10/31の测定において増加量はマ イナスに記録されて招り，これは，その間の台風による 降雨量及び強風による影響と考えざるを得ない。以上の ような気象条件による期間内の溶脱や落下, 流亡を無視 しても, 暴露期間による葉面吸着の増加量を直線によっ て回帰できるむのとすればそれぞれ次式のように求めら れる。

$$
\begin{array}{lr}
\text { カイズカイブキ } & Y=0.1456 X+0.7493 \\
\text { (濃度一高) } & (r=0.8728) \\
\text { カイズカイブキ } & Y=0.0435 X+1.5417 \\
\text { (濃度一低) } & (r=0.7965) \\
\text { マサキグループ } & Y=0.1407 X+1.2192 \\
& (r=0.9705) \\
\text { オオムラサキ } & Y=0.0924 X+2.9281 \\
\text { グループ } & (r=0.8527) \\
\text { ネズミモチ } & Y=0.0709 X+1.2421 \\
\text { グループ } & (r=0.9462)
\end{array}
$$

ただし， $Y$ : 吸着量（カイズカイブキのみ $\mathrm{mg} / \mathrm{g}$, 他 は, $\left.\mathrm{mg} / \mathrm{dm}^{2}\right)$

$X$ :日数

上式で, 定数項は測定開始以前から吸着していた量及 び誤差と考えると，Xの前の定数は，1日当りの増加率 と考党て良い。

カイズカイブキの場合濃度によって増加率に顕著な差 があり（約 3 倍）そそれが濃度差（平均約 3 倍）と直線 的関係が認められる。

(5) 植栽構造とフィルター効果

以上の考察からでも，大気中の浮遊粉塵を吸着させる ための理想的な樹林の構造を提案することができる。た とえば，樹林を構成する樹種は，その葉の形態ができる だけ構造的に複雑で，かつ，小型のものであること，あ るいは, 樹林を污染源 (車道) 飞接近させ, 污染質が大
気拡散する以前の高濃度の段階で吸着させるょうにする こと，などである。しかし，ここで重要なことは，樹林 带が壁を形成して，あたかも防風林のごとく，污染気流 を樹冠飞沿って上方へ流動させてしまったのでは，吸着 効果を持つ樹林帯の意味がなくなってしまうということ である。図一1に示したように，樹林による拡散効果は ，污染源と被害者侧との位置関係によっては評価できよ うが，一般的には，そのような位置関係は現実的ではな いと思われる。すなわち，樹林は，かなり疎で樹林内 飞, 1 本の樹木の場合はその群葉内に, 比較的污染空気 流の侵入し易い状態が全体の吸着量の増加にとって望ま しいことになる。

（6）植栽による大気浄化機能の定式化（固体污染質）

これまでの成果の段階で，樹林全体についての吸着量 を予測式によって示すことは差控えなければならない が，ある稚度，その定式化を予想することはできる。す なわち，(5)の(2)(3)(4)式から粉鹿濃度が樹林全体に一様に 分布していること仮定すれば，次式のようになる。

$$
W=k C D \sum_{i=1}^{n} \alpha_{i} S_{i}
$$

ただし，W:樹林による粉塵の総吸着量 $(\mathrm{g})$ $S i: i$ 樹種の総葉面積または総葉乾量 $\left(\mathrm{cm}^{2}\right)$

$k:$ 粉塵粒子の運動を考慮した無次元の係数 $C:$ 大気中の粉塵濃度 $\left(\mathrm{g} / \mathrm{cm}^{3}\right)$

$D:$ 期間 (day)

$\alpha_{i}: i$ 樹種の単位大気粉塵濃度当りの 粉 塵 吸 着能 $(\mathrm{cm} / \mathrm{day})$

ただし，このモデルは植栽が $1 \sim 2$ 列程度の空気流の 侵入乙易い疎な状態の生垣状のものである場合には，あ る程度対応できようが，いわゆる樹林となると $S$ (総葉 面積または総葉乾重) とW (総吸着量) とは, 直線的に 相関があるとは考えにくい。つまり，内部も含めて樹林 全体に粉塵濃度が一様飞分布しているという仮定は実態 にそぐわず，当然のことながら，污染源に近い葉程吸着 量は多く，その分だけ後方の葉の周辺の粉塵濃度は低下 するはずであり，距離による拡散，希釈もかなり大き w。

すなわち，ここでの問題は発生源からの污染空気流が 樹林内に拈いてどのような流れ（拡散）を示すかであ る。この点に関しては研究例が皆無に近く，確たること をここで提示することはできないが，以上の考察から， 樹林带が道路に沿って十分に長く，かつ，樹冠を越えて 污染気流が移動することなく，樹林内に侵入する（従っ て樹林密度は十分に蹯な場合）として，(5)式を発展させ れば次のようになるものと考えられる。

$$
\begin{aligned}
& W=L_{T} \cdot H_{T} \cdot u \int_{a}^{X-a}\left\{F_{(X)}-C_{(X)}\right\} d X \\
& W=\alpha \cdot L_{T} \cdot P \int_{a}^{X-a} C_{(X)}(X-a) d X
\end{aligned}
$$


ただし， $W:$ 樹林による吸着量 $(\mathrm{mg} / \mathrm{sec})$

$L_{T}, H_{T}$ : 樹林带の延辰 $(\mathrm{m})$ 及び高さ $(\mathrm{m})$

$\alpha$ : 葉面積指数

$u:$ 風速 $(\mathrm{m} / \mathrm{sec})$

$P:$ 樹林による単位面積, 単位時間当り吸 着能 $(\mathrm{m} / \mathrm{sec})$

$F_{(x)}$ : 樹林による吸着量を考慮しない場合の 樹林内の道路中心から道路に直角方向 へ $X \mathrm{~m}$ の距離の濃度 $\left(\mathrm{mg} / \mathrm{m}^{3}\right)$

$C_{(X)}$ : 樹林による吸着量を考慮した同上の距 離に括ける濃度 $\left(\mathrm{mg} / \mathrm{m}^{3}\right)$

$a$ : 道路中心から樹林帯までの距離 $(\mathrm{m})$

さらに, (6)式と(7)式から $C_{(x)}$ を消去すると,

$$
W=\int_{a}^{X-a} \frac{\alpha \cdot P \cdot L_{T} \cdot H_{T} u(X-a)}{\alpha P(X-a)+H_{T}^{-} u} F_{(X)} d_{X}
$$

また、Wを消去すると

$$
C_{(X)}=\frac{H_{T} \cdot u}{H_{T} \cdot u+\alpha P(X-a)} F_{(X)}
$$

となる。図一15は(9)式を $F_{(X)}$ に風速 $1 \mathrm{~m} / \mathrm{s}$ 時のプルー ムモデルを採用し，その他以下の条件をもとに樹林幅ご とに $F_{(X)}$ と $C_{(X)}$ を求めたものである。

\section{計算条件}

$F_{(X)}$ : 発生源を線煙源としたプルームモデル

$$
\begin{aligned}
& F_{(X)}=\frac{Q}{\sqrt{2 \pi} \sigma_{z} u}\left\{\exp \left[-\frac{(z-H)^{2}}{2 \sigma_{z}^{2}}\right]\right. \\
& \left.\quad+\exp \left[-\frac{(z+H)^{2}}{2 \sigma_{z}^{2}}\right]\right\}
\end{aligned}
$$

$Q: 0.1463\left(\mathrm{mg} / \mathrm{m}^{3}\right)-4$ 車線道路, 750 台/車線・ $\mathrm{hr}$, 車種混入率 (小型: 中型: 大型 $=0.4$ : $0.3: 0.3)$ に市ける排出強度 ${ }^{12)}$

$\sigma_{z}: \sigma_{z}^{2}=\frac{1}{2} C_{z}{ }^{2} X^{2-n} \longrightarrow$ Sutton の拡散パラメー夕

より, $C_{z}=0.12, n=0.25$ （大気安定度・中 立の場合), ただし初期拡散幅 $\sigma_{z 0}=1.5$ とす る13)。

$z: 1.5(\mathrm{~m})$ 一 予测点の地上高, この場合は樹 林の垂直方向の平均濃度と仮定

$H: 1(\mathrm{~m})$ 一一線煙源の地上高

$u: 1(\mathrm{~m} / \mathrm{s})$ 一風速

$P: 3.7834 \times 10^{-4}(\mathrm{~m} / \mathrm{s})$ - (4) 式中のネズミモチ グループを採用（実験結果中，もっとも控え 目な数値)。

$(365 \times 0.0709+1.2421) \times 1.1 \mathrm{~g} / \mathrm{dm}^{2} \cdot \mathrm{yr}, \quad 大$ 気濃度 $0.25 \mathrm{mg} / \mathrm{m}^{3}$

$\alpha: 3.6$ 一常緑広葉樹林の葉面積指数 $5 \sim 914$ ) の中央值の約 $1 / 2$ (密植しないため)。

$H_{T}: 5(\mathrm{~m})$

$L_{T}: 500(\mathrm{~m})$

$a: 10(\mathrm{~m})$

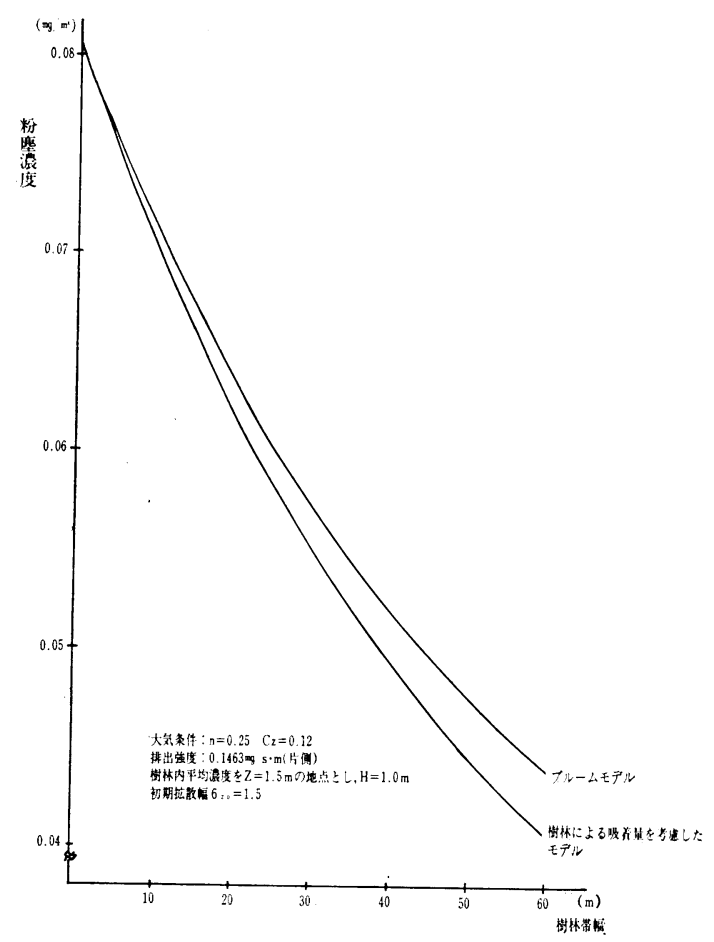

図一15樹林による吸着量を考虑した粉塵濃度

以上の条件下では樹林帯幅 $30 \mathrm{~m}$ で3. $8 \%, 60 \mathrm{~m}$ で7. $5 \%$ 程度の樹林带による濃度減少が認められるのである。ま た同一の計算条件で8式により吸着量を求めると（きざ み幅 $1 / 20000$ の台形法則飞よる)，樹林帯幅 $20 \mathrm{~m}$, 延長 $500 \mathrm{~m}$ によって年間抢よそ $20 \mathrm{~kg}$ の粉應吸着量が認められ たのである。ただし，以上の計算では風向が樹林帯方向 に一定であるとしており，現実とはかならずしも一致し ないであろう。樹林带幅を道路片側に $20 \mathrm{~m}$ とせず，両側 に各 $10 \mathrm{~m}$ とし同一延長ならば, $20 \mathrm{~kg} / \mathrm{yr}$ 以上の吸着量と なるはずである。な特，前述したように，吸着量には限 界があり，その1つのクライテリアとしては、生育条件 からくる致死量的な考え方があるが，いずれにしるそれ は，単に濃度だけではなくガス状河染質の吸収量に沶い て，国立公害研究所 ${ }^{15)}$ が示しているドースの概念，すな わち $(P \times D)$ としてとらえることが妥当であると思わ れる。

(1980.9.4. 受付 1981.2.21受理)

\section{引用文献}

1) 佐々木祐三：自動車排出ガス㧓散の基本的な考え 方，日本道路公団技術情報 44，7-29，1978

2 ）環境庁：昭和54年版環境白書, 1-7, 環境庁, 1979

3 ）新田伸三 : 環境緑地 II，植栽の理論と技術，117119, 鹿島出版会, 1975

4 ）嶋村晴夫ら：自動車排ガス公害一その実態と対策一 
4-16, 化学工業社, 1971

5 ）増田芳雄 : 植物生理学, 133-134, 培風館, 1977

6 ) 本多侔: 防煙林の効果飞関する調査研究報告書, 35 -55, 日本道路公団, 1972

7 ）辰見修三：緑地環境機能論, 91-183, 地球社, 1975

8 ) 斉藤隆幸ら (門司・内嶋編): 大気環境の科学 5 , 大気環境の変化と植物, 40-46, 東京大学出版会, 1979

9) A. C. Chanberlain: The Movement of Particles in Plant Comunities, Vegetation and the Atmosphere, Vol. 1, 155-203, Academic Press, 1976

10) 内田正也：林带による大気活染軽減効果, 空気清浄
6, 1

11) Th. Keller/H. Preis : Schweis z Forstwes, 118, 143-162, 1967 (林業経営研究所編, 都市林, 121, 1972より）

12）建設省道路局：環境影響予測飞用いる自動車排出力 スの排出係数 (案), 建設省道路局, 1978

13）建設省道路局：道路環境評価飞用いる予測方法(案) 建設省道路局, 1978

14）依田恭二 : 森林の生態学, 34-42, 築地書館, 1974

15）国立公害研究所：陸上植物による大気污染環境の評 価と改善に関する基礎的研究一昭和 $51 \cdot 52$ 年度研究 報告一, 環境庁. 1978

Summary : Lately, particulate pollutants that are exhausted by motor vehicles have become an issue. The author made some experiments on trapping the particulates by foliage for explaining the atmospheric purification as a function of buffer planting belts on roadsides. The site of the experiments were near the eastern portal of Nihonzaka tunnel of Tomei-expressway, and ring road Route 7 and 8 in Tokyo. The results of this paper are summarized as follows:

The quantity of particulates trapped by foliage was related to property of the leaves. Small leaves with complicated structure such as serrations, veins and downs were better for increasing of the quantity.

As a result of long term experiments at Tomei-expressway, the quantity was related to the exposed term, and their regression equation was a linear one with a high correlation coefficient in spite of passable rainfall and wind during the term.

And the quantity was related linearly to a concentration of particulate pollutants in the air near the foliage. For that reason, it is necessary for increasing the quantity that the planting site is as near as possible to the source of the pollutants and the polluted air is positively induced into the foliage.

Based upon the results, the quantity of particulates trapped by the buffer planting belt that does not have dense foliage was estimated by computer. At normal atmospheric condition and for a normal arterial road with four lanes, the value obtained was approximately $20 \mathrm{~kg} /$ year in case of the planting belt of $20 \mathrm{~m} \times 500 \mathrm{~m}$ (1ha). 